\title{
Incorporating the Water Footprint and Virtual Water into Policy: Reflections from the Mancha Occidental Region, Spain
}

\author{
Maite M. Aldaya • Pedro Martínez-Santos • \\ M. Ramón Llamas
}

Received: 3 December 2008 / Accepted: 3 July 2009 /

Published online: 15 July 2009

(C) The Author(s) 2009. This article is published with open access at Springerlink.com

\begin{abstract}
Water resource management is often a controversial issue in semiarid regions. Most water resources experts admit that water conflicts are not caused by the physical water scarcity but they are mainly due to inadequate water management. The virtual water concept (the volume of water used in the production of a commodity, good or service) together with the water footprint (indicator of water consumption that looks at both direct and indirect water use of a consumer or producer), links a large range of sectors and issues, thus providing a potentially appropriate framework to support more optimal water management practices by informing production and trade decisions. This paper provides an analysis of these two concepts within the context of the Mancha Occidental region, Spain, exploring the hydrological and economic aspects of agricultural production. In doing so, this work not only distinguishes between green and blue water but also between surface and groundwater. We conclude by discussing the practical implications of the results, as well as their potential limitations from the policy standpoint.
\end{abstract}

Keywords Virtual water - Water footprint • Green water • Blue water • Groundwater intensive use $\cdot$ Mancha Occidental

\section{Introduction}

In most arid and semiarid countries water resources management is an issue as important as controversial. Today most water resources experts admit that water

\footnotetext{
M. M. Aldaya $(\varangle)$

Twente Water Centre, University of Twente, Room Horst W-119, 7500 AE Enschede, The Netherlands e-mail: M.M.Aldaya@ctw.utwente.nl

P. Martínez-Santos · M. R. Llamas

Department of Geodynamics, Complutense University of Madrid, Madrid, Spain
} 
conflicts are not caused by the physical water scarcity but they are mainly due to poor water management. By linking a large range of sectors and issues, virtual water and water footprint analyses provide an appropriate framework to find potential solutions and contribute to a better management of water resources. Take for instance the case of Spain, whose Ministry for the Environment recently enacted a regulation to use the water footprint as a tool for the implementation of the River Basin Management Plans prescribed by the EU Water Framework Directive (WFD).

The water footprint is a consumption-based indicator of water use that looks at both direct and indirect water use of a consumer or producer (Hoekstra and Chapagain 2007, 2008). Closely linked to the concept of water footprint is that of virtual water. The virtual water content of a product (a commodity, good or service) refers to the volume of water used in its production (Allan 1997, 1999; Hoekstra 2003). Building on this concept, virtual water 'trade' represents the amount of water embedded in traded products (Hoekstra and Hung 2005).

A nation can preserve its domestic water resources by importing water intensive products instead of producing them domestically. 'Water savings' can in turn be used to produce alternative, higher-value agricultural crops, support environmental services or serve growing domestic needs. Thus, virtual water 'import' is increasingly perceived as an alternative source of water as well as an opportunity to preserve environmental flows in water-stressed nations, and is slowly changing the prevailing paradigms of water and food security.

In this sense it is important to establish the source of water, be it rainwater evaporated during the production process (green water) or the surface water and/or groundwater consumed (blue water) (Falkenmark 2003; Chapagain et al. 2006). Traditionally, emphasis has been given to the concept of blue water through the use of irrigation systems. However, an increasing number of authors highlight the importance of green water (Rockström 2001; Falkenmark and Rockström 2004; Allan 2006; Comprehensive Assessment of Water Management in Agriculture 2007). Virtual water and water footprint assessment could thus inform production and trade decisions, promoting the production of those goods most suited to local environmental conditions as well as the development and adoption of water efficient technologies. Nevertheless, this approach requires a good understanding of the impacts of such policies on socio-cultural, economic and environmental conditions, both at the catchment and user scales.

The present paper analyses virtual water 'trade' and the water footprint of agricultural production, considering both economic and hydrological aspects and differentiating between the sources of water (green, surface blue and ground blue) in the Mancha Occidental region, Spain. Since agriculture is the main (green and blue) water user, this sector is at the centre of the present study. The water footprint analysis provides a multidisciplinary framework that draws new insights in relation to the region's long-standing conflicts between farmers and conservationists.

\section{Objectives}

This paper provides a joint economic and hydrological perspective on virtual water 'trade' and the water footprint of the Mancha Occidental region, Spain, exploring the 
connections between water use, food production and environmental management. Focusing on the agricultural sector, which accounts for $95 \%$ of the area's water uses, the following pages establish the virtual water content of the crops, the agricultural economic productivity and the implicit virtual water 'trade' under different climatic conditions. Despite its limitations we argue that methodologies such as this may provide a transparent and multidisciplinary framework for optimal water policy decisions, while also contributing to the implementation of the EU Water Framework Directive.

This work highlights the imperative challenge of considering economic and ecological aspects, following the widely accepted paradigm "more cash and nature per drop" (Aldaya and Llamas 2008). Due to the limited information available, specific quantitative data on environmental water requirements have not been included in the present report. On the other hand, this study distinguishes between green and blue surface and groundwater, which is perceived as innovative and potentially relevant for water policy, while also exploring the practical limitations of the tools.

\section{Methodology}

\subsection{Study Area}

The Mancha Occidental region is located within the Upper Guadiana basin, Spain (Fig. 1). The area features a predominantly flat landscape, sloping gently over a $150 \mathrm{~km}$ distance from the northeast (altitude $730 \mathrm{~m}$ above sea level) to the southwest $(600 \mathrm{~m})$. Climatic conditions are typically continental and semiarid. Long dry periods

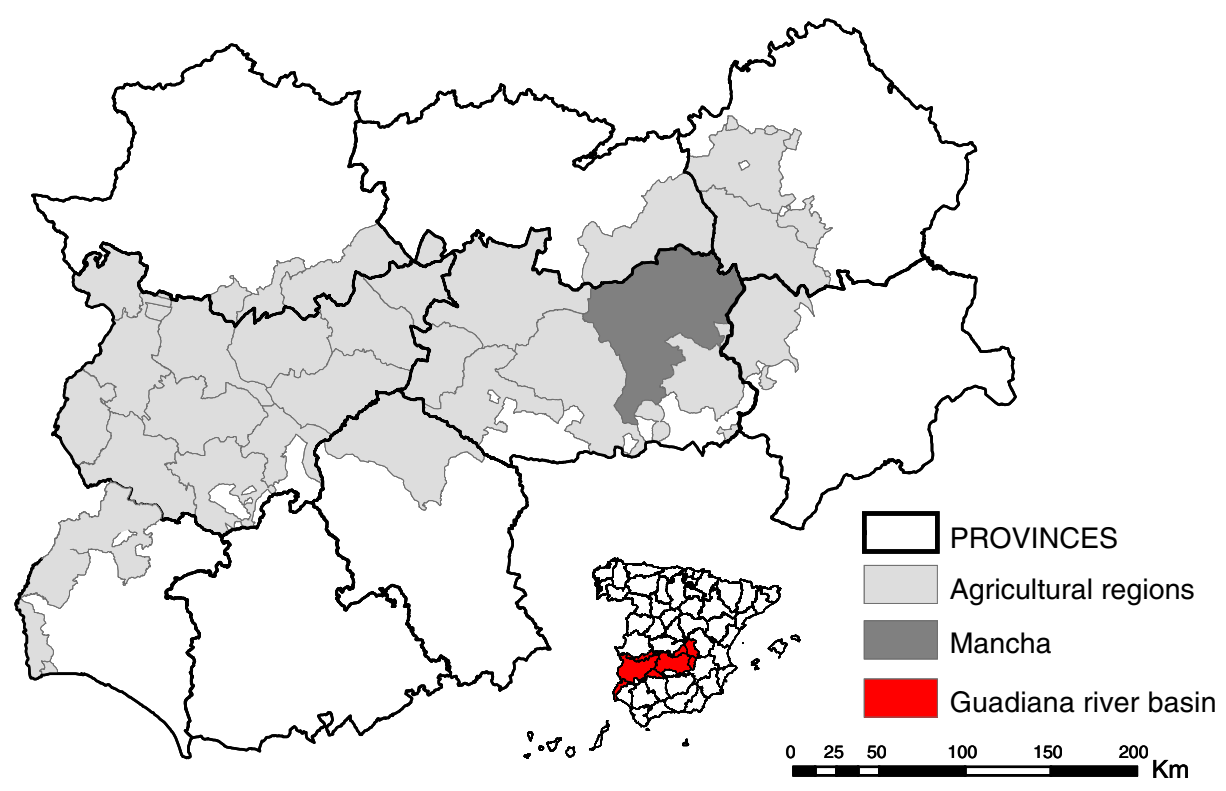

Fig. 1 Mancha agricultural region within the Guadiana river basin. Modified from CHG (2008a) 
alternate with short wet sequences, and hot dry summers follow short mild winters. Mean temperatures range from a $5^{\circ} \mathrm{C}$ in winter to about $25^{\circ} \mathrm{C}$ in summer, while rainfall averages approximately $415 \mathrm{~mm}$ /year (Martinez-Santos et al. 2008a).

Groundwater is the only reliable water resource, surface water being limited to a few small reservoirs and series of small creeks that may run dry for years at a time. Approximately $95 \%$ of the area's water supplies traditionally come from the aquifer (CHG 2008a). The Mancha Occidental region spans 470,000 ha, of which 390,000 ha correspond to agricultural surfaces (Table 1). A significant proportion of the crop area is devoted to irrigation (38\%), thus exceeding Spain's 22\% average (MIMAM 2007).

Grapes and cereals are the most important crops in the region, both as regards rainfed and irrigated agriculture (Fig. 2). Causes should be found in the distant past, as well as in the 2003 Common Agricultural Policy reforms (MAPA 2006). According to Garrido and Varela-Ortega (2008), the increase in irrigated grapes and olives has been notable in the region over the last 5 years. Current market trends and technological advances suggest that changes in crop distribution will continue to occur along these lines in the near future.

On the other hand, the Mancha Occidental region provides a stark example of inappropriate groundwater management (Bromley et al. 2001; Llamas and MartínezSantos 2005). During the last three decades the region has enjoyed a noteworthy social and economic development due to the growing importance of groundwaterbased irrigation. However, little forethought went into how to carry out this development. Individuals traditionally drilled their own wells without consent from the Water Authority, and for years pumped as much groundwater as they wished. Uncontrolled exploitation depleted the water table at a constant rate of $1 \mathrm{~m} /$ year, thus drying up a series of Ramsar-listed wetlands (Llamas 1988; Fornes et al. 2000; Martinez-Santos et al. 2008a). This gave rise to a variety of social conflicts between the Water Authorities, farmers and environmental conservation organizations. Conflicts currently transcend the local scale, as an existing inter-basin water transfer is the source of bitter disputes between the Mancha Occidental and other neighbouring regions.

In the dawn of the Water Framework Directive, which establishes the obligation to restore the ecological health of all EU water bodies, adequate tools are required to address potential tradeoffs between irrigated production and environmental flows. It is within this context that the virtual water and water footprint concepts may prove valuable.

\subsection{Methodological Approach}

The present study estimates the virtual water and water footprint of production for the Mancha agricultural region considering the green and blue (surface and ground) water components for the most representative crops. The virtual water and water footprint are calculated following the methodology developed by Hoekstra and Chapagain (2008). A succinct methodological description is provided below, while a more comprehensive one can be found in Aldaya and Llamas (2008).

As defined above, the virtual water content of a given good or commodity is the volume of freshwater used for its production, which in turn depends on the water use in the various steps of the production chain. In the case at hand, this 


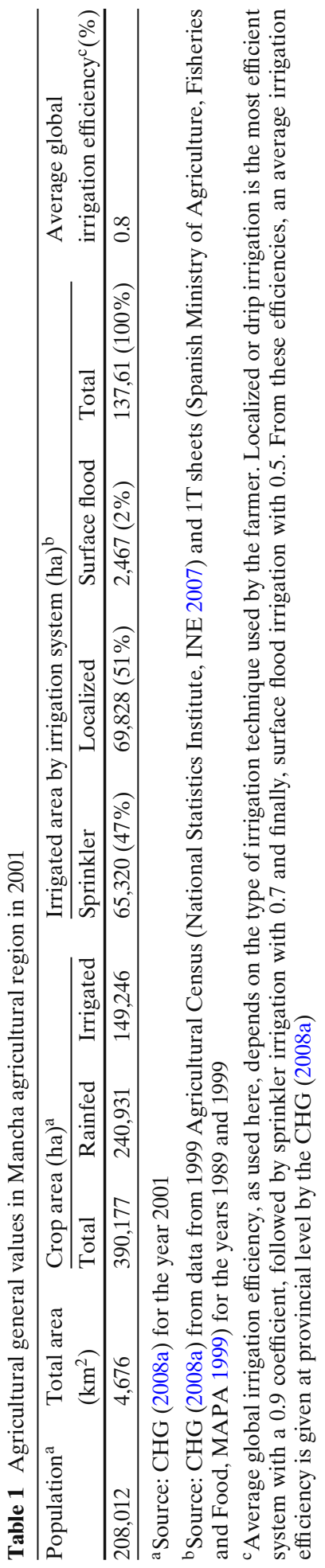




\section{Irrigated agriculture}

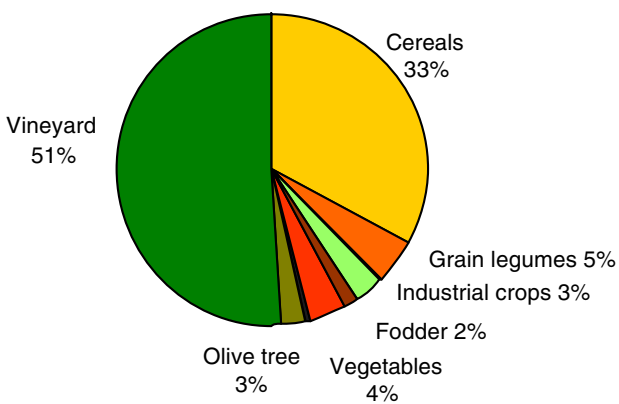

Rainfed agriculture

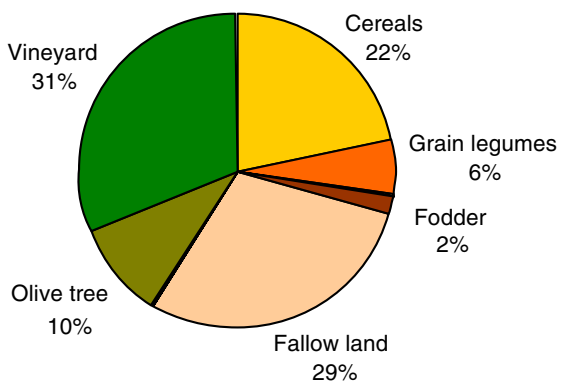

Fig. 2 Crop area percentage of irrigated and rainfed agriculture in Mancha region (average-year 2001). Showing crops occupying over $1 \%$ of land. Source: CHG (2008a)

essentially refers to primary crops (i.e. crops as they come directly from the land, without having undergone any processing), and is measured in $\mathrm{m}^{3} /$ ton. The virtual water content of primary crops is calculated as the ratio between the volume of water used during the entire period of crop growth (crop water use, $\mathrm{m}^{3} / \mathrm{ha}$ ) and the corresponding crop yield (ton/ha). In other words, crop water requirements present two components: effective rainfall (green water) and irrigation water (blue water). Crop water requirements ( $\mathrm{mm} /$ day) refer to the water needed for evapotranspiration under ideal growth conditions, measured from planting to harvest. For the purpose of this work these have been estimated with the CROPWAT model (Allen et al. 1998; FAO 2003).

Rainfed and irrigated agriculture are thus differentiated in the green and blue virtual water component calculations. The green component $\left(V_{\mathrm{g}}, \mathrm{m}^{3} /\right.$ ton $)$ is calculated as the ratio between green crop water use $\left(\mathrm{CWU}_{\mathrm{g}}, \mathrm{m}^{3} / \mathrm{ha}\right)$ and crop yield $\left(Y\right.$, ton/ha). The blue component $\left(V_{\mathrm{b}}, \mathrm{m}^{3} /\right.$ ton $)$ is calculated as blue crop water use $\left(\mathrm{CWU}_{\mathrm{b}}, \mathrm{m}^{3} / \mathrm{ha}\right)$ divided by the crop yield $(Y$, ton/ha). Since yield is different for rainfed $\left(Y_{\mathrm{r}}\right)$ and irrigated lands $\left(Y_{\mathrm{irr}}\right)$, each has been estimated separately: a single green component for rainfed crops:

$$
V_{\mathrm{g}}=\frac{C W U_{\mathrm{g}}}{Y_{\mathrm{r}}}
$$

and separate green and blue virtual water components for irrigated primary crops:

$$
\begin{aligned}
V_{\mathrm{g}} & =\frac{C W U_{\mathrm{g}}}{Y_{\text {irr }}} \\
V_{\mathrm{b}} & =\frac{C W U_{\mathrm{b}}}{Y_{\text {irr }}}
\end{aligned}
$$

In this study we have included the concept of water economic productivity $\left(€ / \mathrm{m}^{3}\right)$ to assess the production value, expressed in market price (€/ton) per cubic meter of water required when producing the commodity $\left(\mathrm{m}^{3} /\right.$ ton $)$ for the years 1997,2001 and 2005 (MAPA 2007). In a similar way, land economic productivity represents the economic value of farm output per hectare cultivated (€/ha) (ibid.). 


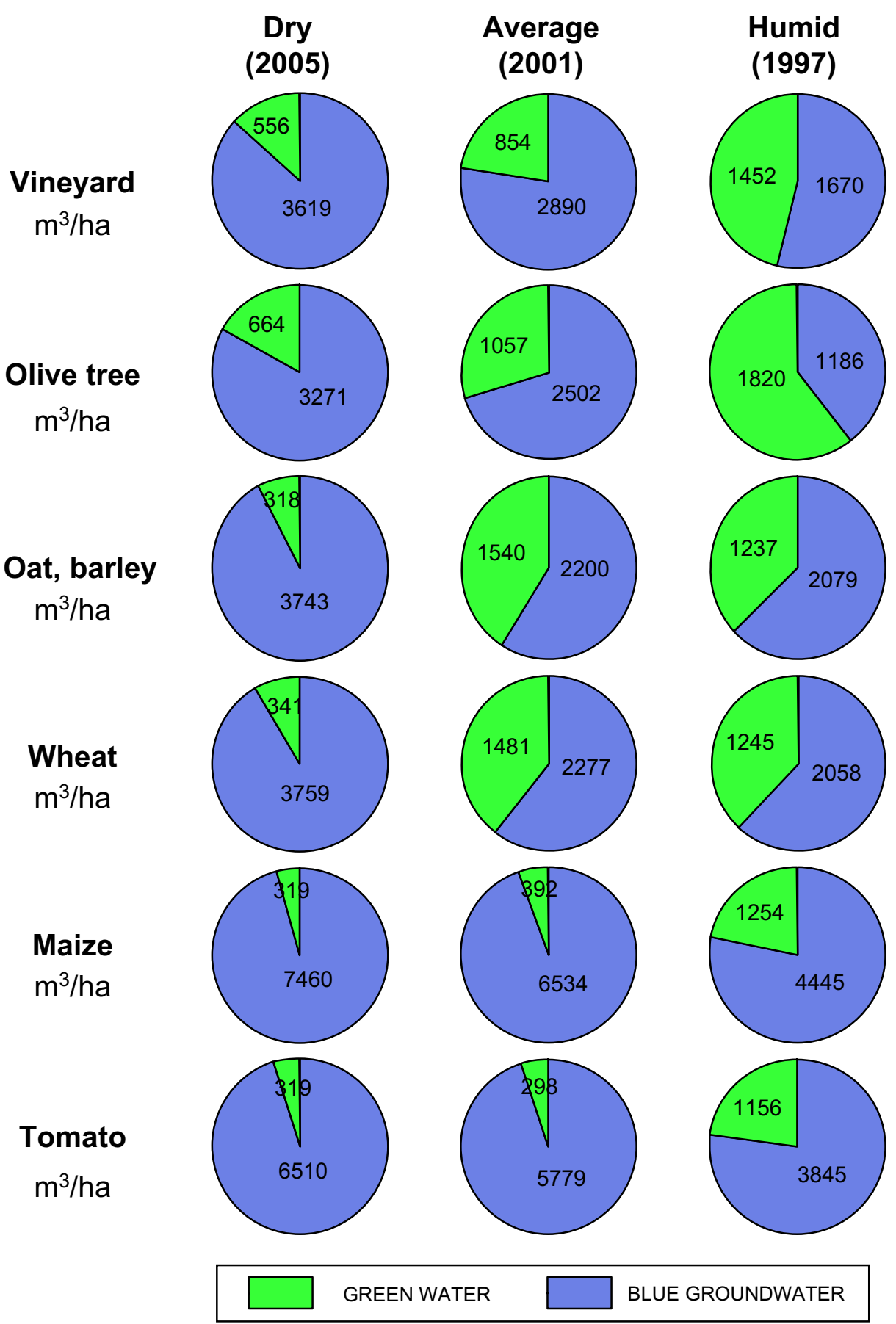

Fig. 3 Green and blue water consumption ( $\mathrm{m}^{3} / \mathrm{ha}$ ) per crop and year in Mancha agricultural region assuming that evapotranspirative demands (using CROPWAT program) are completely satisfied. Source: own elaboration 
The water footprint is an indicator of water use that looks at both direct and indirect water use of a consumer or producer (Hoekstra 2003). A water footprint can be calculated for any well-defined group of consumers (e.g. an individual, family, village, city, province, state or nation) or producers (e.g. a public organization, private enterprise or economic sector). The present study calculates the water footprint of agricultural production per sub-basin. This accounts for all of the water used in the sub-basin regardless of where the products are actually consumed and is useful to examine the stress placed on a region's water resources (WWF 2008). In addition, trade data at a provincial level are presented separately (ICEX 2008). In this way policy makers could explicitly consider options to save water through import of water-intensive products. This can also provide a hint on whether exported products are related to water depletion or pollution in the producing region.

A number of simplifications have been assumed for calculation purposes. First of all, the CROPWAT model assumes that the crop water requirements are satisfied by irrigation. The examples found in the literature also show that there are certain differences in the results depending on the level and source of data used. It is therefore essential to clarify the place and period under consideration. Secondly, the study refers to the area's mainstream crops, which comprise $70 \%$ of the total agricultural surface. The remaining $30 \%$ is distributed in a variety of minoritarian crops for which there is little or no data. These are extrapolated to $100 \%$ of the total cultivated area. Third, the effect of climate variability on water use is taken into account by considering three typical weather conditions, namely, humid, average and dry years. Respectively, the years 1997, 2001 and 2005 have been considered representative of each of these three categories. Moreover, some inaccuracies may also arise from inadequate water management data. This includes uncertainties as to the inventory of water users and rights, as well as to the total area irrigated by legal and illegal water wells.

Data generally correspond to the Mancha agricultural region (CHG 2008a). Whenever this was not available, we have extrapolated from provincial-scale data.

\section{Dry}

(2005)

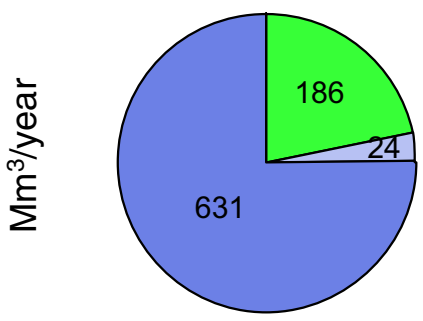

Average

(2001)

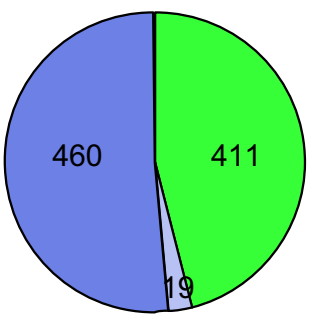

Humid

(1997)

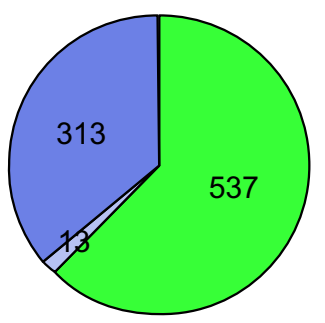

GREEN WATER

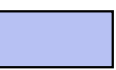

BLUE SURFACE WATER

Fig. 4 Green and blue water footprint of agricultural production $\left(\mathrm{Mm}^{3} /\right.$ year $)$ in Mancha agricultural region in a dry, average and humid year. Source: own elaboration 


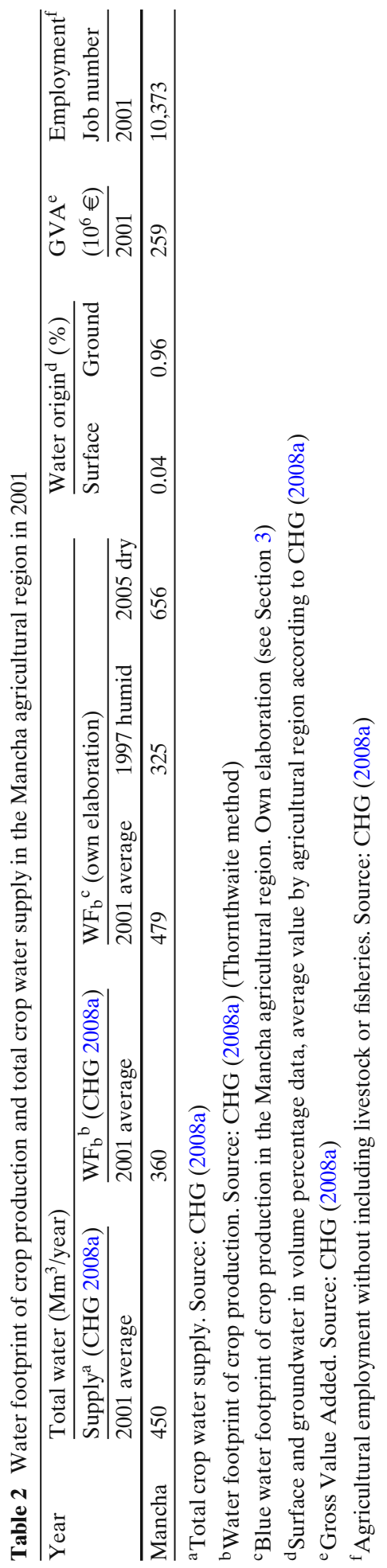


This is the case of the average monthly rainfall and evapotranspiration data (INM 2007), rainfed and irrigated yield per crop (MAPA 2007), average irrigation efficiency (CHG 2008a), crop calendar (MAPA 2001) and trade data (ICEX 2008).

\section{Results}

Figure 3 presents the theoretical crop water consumption $\left(\mathrm{m}^{3} / \mathrm{ha}\right)$ by irrigated crops according to the CROPWAT model results. The crop water consumption refers to the accumulation of daily evapotranspiration over the complete growing period, from planting to harvest. This model considers that all theoretical evapotranspirative crop demands are satisfied by irrigation.

Interesting patterns emerge from the water footprint of both rainfed and irrigated farming production ( $\mathrm{Mm}^{3}$ /year) (Fig. 4). While these are roughly similar under each weather condition (about 800-900 $\mathrm{Mm}^{3}$ ), remarkable variations can be observed in the proportion of green and blue water footprints. As expected, the blue water footprint is higher in dry years and lower in humid years, to the point that the blue water footprint of crop production during dry years almost doubles humid years. The green water footprint presents the opposite pattern.

Table 2 shows how the water footprints estimated in this study ( $\mathrm{Mm}^{3} /$ year) are somewhat higher than those given by official sources (CHG 2008a). There are, however, remarkable water footprint variations in the different types of rainfall years. In comparison with other regions in the basin, the water footprint is close to the total crop water supply numbers in the Mancha Occidental region. This is probably attributable to the high efficiency of irrigated agriculture, characterized by drip and sprinkler irrigation systems (Table 1). The groundwater footprint is also observed to present some discrepancies in regard to the official groundwater abstraction figures (Table 3, Fig. 4). While this could be partly attributed to methodological issues, it is more likely the result of uncertainties in management data. These often stem from not considering water saving policies or land-use changes, as well as from the implications of widespread illegal pumping.

Maize and vegetables are generally considered water-intensive crops, since their requirements in terms of $\mathrm{m}^{3} / \mathrm{h}$ a are quite high. Conversely, cereals and olives have a reputation for being water-effective. Nevertheless, the results of this analysis show olives and cereals to have the highest blue virtual water contents in terms of $\mathrm{m}^{3} / \mathrm{kg}$ (Fig. 5), whereas the virtual water content of maize and vegetables is

Table 3 Water abstractions in the Upper Guadiana basin according to the Water Authority compared with the theoretical blue crop consumptive groundwater use in the Mancha agricultural region

\begin{tabular}{lll}
\hline Year & Water abstractions after $\mathrm{CHG}^{\mathrm{a}} \mathrm{Mm}^{3}$ & Theoretical $\mathrm{CWU}_{\mathrm{b}}^{\mathrm{b}}\left(\mathrm{Mm}^{3}\right)$ \\
\hline Humid-1997 & 417 & 313 \\
Average-2001 & 387 & 460 \\
Dry-2005 & 387 & 631 \\
Average 1980-2005 & 383 & \\
\hline
\end{tabular}

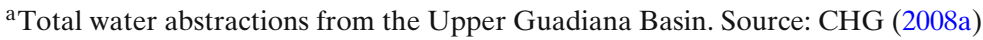

${ }^{\mathrm{b}}$ Theoretical blue crop consumptive groundwater use in the Mancha agricultural region. Own elaboration following FAO (2003) 
Vineyard

Olive tree
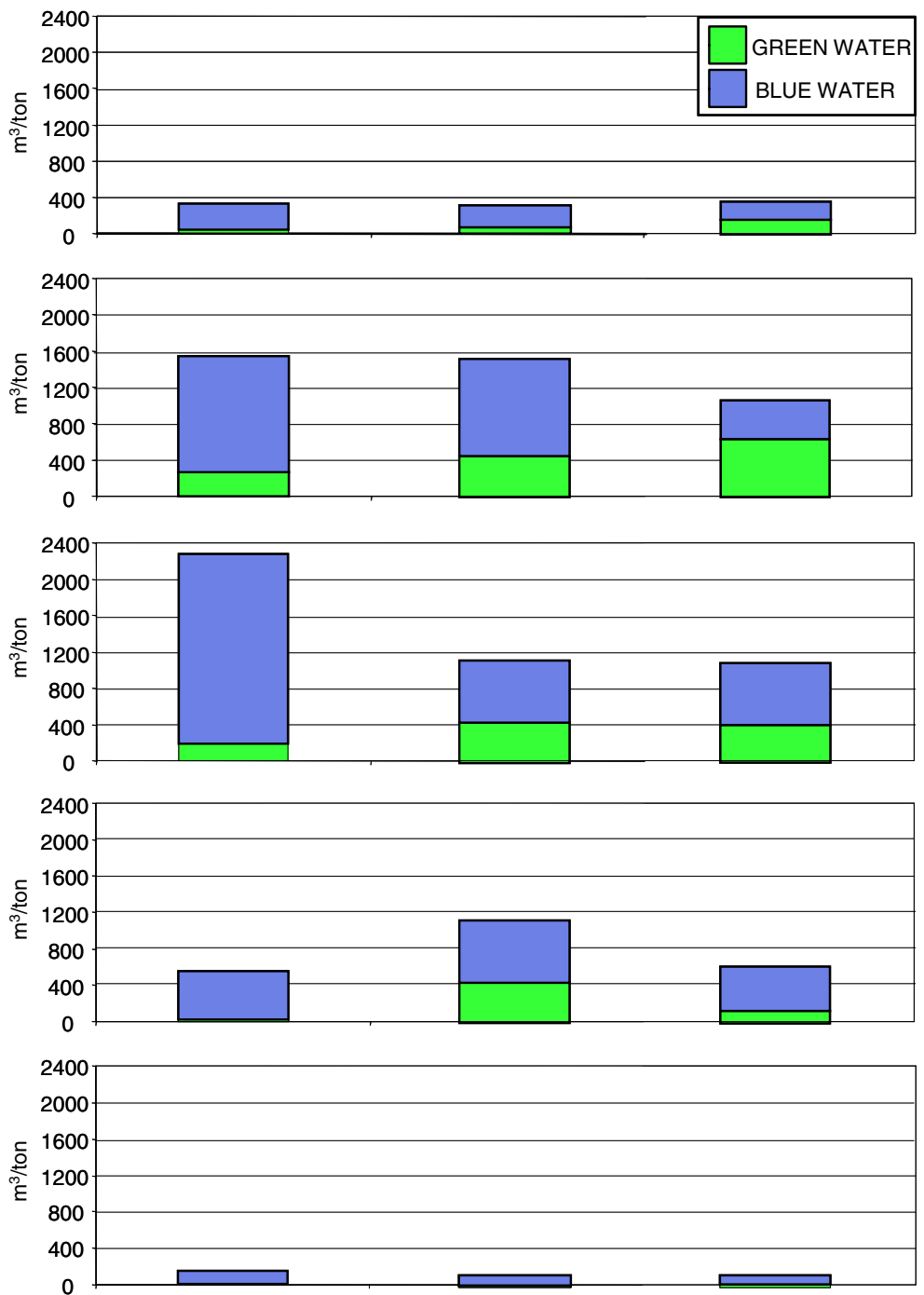

Dry (2005) Average (2001) Humid (1997)

Fig. 5 Irrigated agriculture green and blue virtual content per crop and year in Mancha ( $\mathrm{m}^{3} /$ ton). Source: own elaboration

lower. Tomatoes in turn exhibit the lowest virtual water content, largely due to high yields. In this particular case, it is observed that the drier the year the higher the productivity.

Figure 6 shows the differences in the economic productivity per hectare (€/ha) of the different rainfed and irrigated crops. While tomato and vegetables are in general more productive, their markets have proved more volatile. Significant tomato price fluctuations were found for the years under consideration, ranging from $522 €$ /ton in a dry year to $310 € /$ ton in a more humid year (MAPA 2007). 


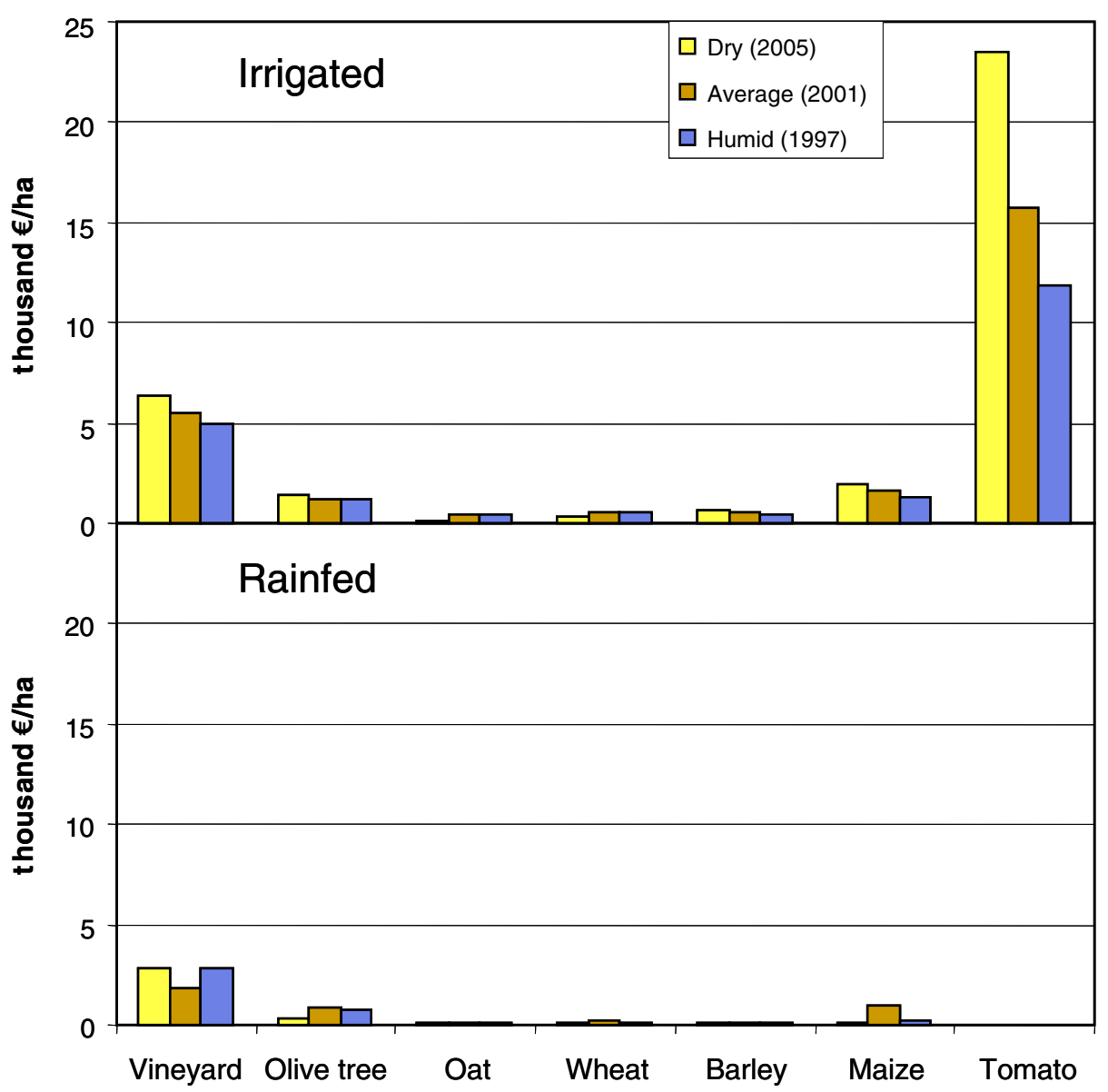

Fig. 6 Land economic productivity in Mancha agricultural region (thousand $€ /$ ha). Source: own elaboration

The economic productivity of irrigated agriculture is normally higher than that of rainfed agriculture (Hernández-Mora et al. 2001; Berbel 2007). From a socioeconomic perspective, irrigated agriculture provides a higher and safer income. This is due to the higher diversification it allows as well as to the reduction of climate risks derived from rainfall variability (Comprehensive Assessment of Water Management in Agriculture 2007). The same argument holds in this study no matter whether the year is humid, average or dry.

\section{Discussion}

\subsection{Towards an Efficient Allocation of Water Resources}

Perhaps one of the most important aspects of this study is the economic water productivity analysis. In arid or semiarid industrialized countries, such as the case 
of Spain, economic and environmental determinants are becoming increasingly important. This means that, either consciously or unconsciously, the long-standing paradigm "more crops and jobs per drop" is shifting towards "more cash and nature per drop". As a result, knowing the economic water productivity of different crops and the source of irrigation water is becoming increasingly important.

Water economic productivity $\left(€ / \mathrm{m}^{3}\right)$ depends not only on climatic conditions and crop yields, but also on the efficiency of water use. In line with existing data, groundwater-irrigated agriculture has a higher productivity when compared with surface water irrigation (Hernández-Mora et al. 2001; Vives 2003). Some of the reasons are the greater control and supply guarantee groundwater provides, which in turn allows farmers to introduce more efficient irrigation techniques; as well as the fact that users bear all private costs, thus paying a higher price per volume of water used than irrigators using surface water. This motivates them to look for more profitable crops that will allow them to maximize the return on their investments and to use water more efficiently (Hernández-Mora et al. 2007). The advantages of groundwater-based agriculture become more prominent during severe drought periods, since groundwater farmers have a guaranteed water supply (HernándezMora et al. 2001; Vives 2003; Hernández-Mora et al. 2007).

Figure 7 shows economic water productivity to vary widely. Crops with a low virtual water content and high economic value, such as tomatoes, present the highest economic water productivities $\left(2-3 € \in / \mathrm{m}^{3}\right)$. This is extensive to other high-value water-effective vegetables. Wine grapes $\left(1-2.5 € / \mathrm{m}^{3}\right)$ and olives $\left(0.3-0.8 € / \mathrm{m}^{3}\right)$ are the second and third most profitable crops.

From the virtual water standpoint, cereals consume around 1,000-1,300 $\mathrm{m}^{3} /$ ton. On the other hand, maize, tomato and melons present the most efficient figures (around 100-200 $\mathrm{m}^{3}$ /ton). This is largely due to high yields. However, cereals are harvested with high dry matter and low (real) water content, whereas in the case of melons and tomatoes the real water content values are very high.

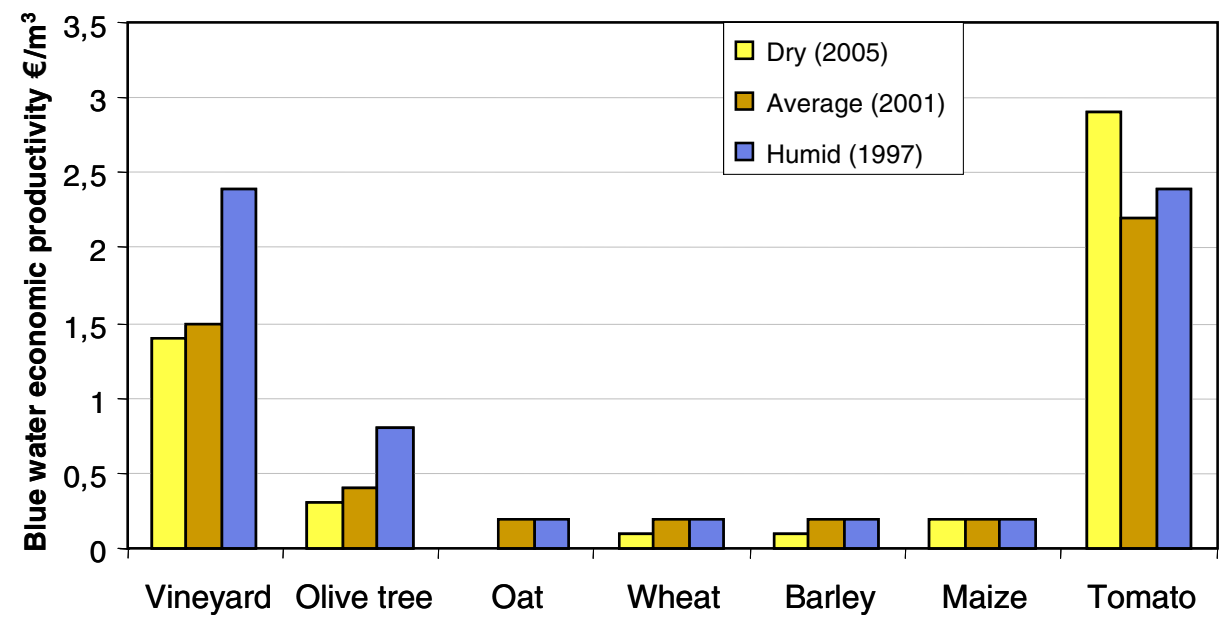

Fig. 7 Blue water economic productivity $\left(€ / \mathrm{m}^{3}\right)$ concerning agricultural water supply by crop and year in Mancha. Source: own elaboration 
Blue water economic productivity ranges between $0.1-0.2 € / \mathrm{m}^{3}$ for low-cost cereals and $2-3 € / \mathrm{m}^{3}$ for vegetables. For wine grapes and olives blue water economic productivity is higher in humid years. This could be explained by a number of factors, such as the higher blue water evapotranspiration in dry years (since smaller quantities of green water are available) or market price fluctuations. The inverse trend is observed in the case of tomato production, which is almost exclusively dependent on blue water.

Overall, high virtual-water low-economic value crops such as cereals are widespread in the region. In contrast, vegetables seem to be the most profitable crops, even if more intensive in terms of water use and chemical inputs per hectare, followed by grapes and then olives. The low water consumption and high economic value of vineyards suggest that these crops could play an important role in achieving an efficient allocation of water and economic resources.

Trade figures in terms of tonnes, euros and virtual water show the region to be a net virtual water 'exporter' (Fig. 8). In this case, the national virtual water figures of the different crop-derived products were used as provided by Chapagain and Hoekstra (2004). As expected, wine plays a substantial role in the calculations. Conversely, the region relies on its own water to produce food, barely importing
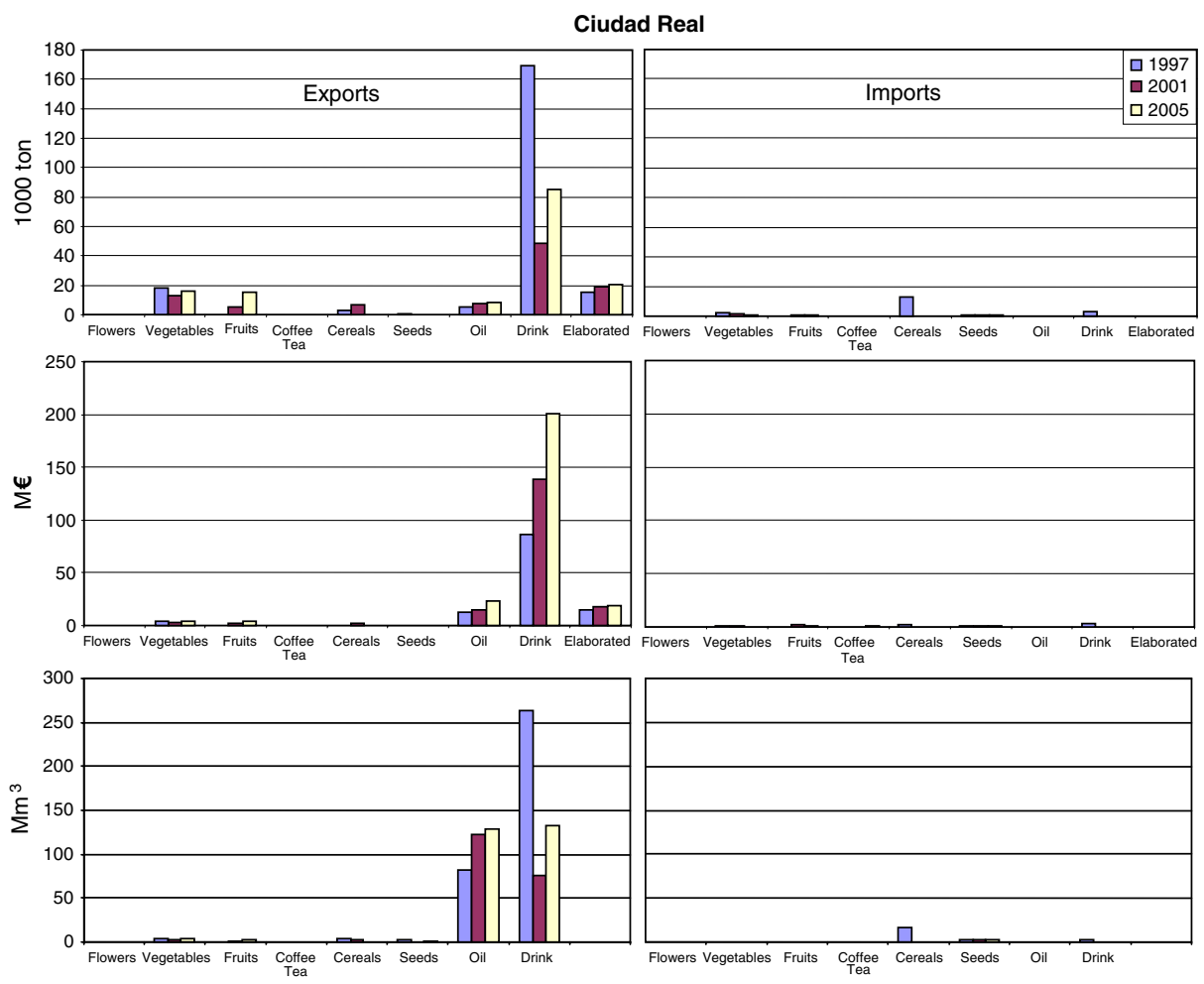

Fig. 8 Agricultural commodity export and import in thousand tonnes, million euros and million cubic metres from Ciudad Real during the years 1997 (humid), 2001 (average) and 2005 (dry). Source: own elaboration based on ICEX (2008) and Chapagain and Hoekstra (2004) data 
anything from outside markets. While this implies a low degree of dependability, it also suggests that there is room for virtual water 'imports' in order to support the existing plans to restore the area's degraded water bodies.

\subsection{Implications of the Water Footprint and Virtual Water Analysis for the Regional Water Policy}

Historically, the social and economic benefits of 'exporting' virtual water have been undeniable, albeit obtained at the expense of the environment. Indeed, a dropping water table has endangered internationally renowned wetlands such as Las Tablas de Daimiel National Park, a Ramsar site which also belongs to the "Mancha Húmeda" UNESCO Biosphere Reserve. This in turn has led to long-lasting conflicts between farmers, water authorities, agricultural policy-makers and ecosystem restoration advocates, and poses a significant difficulty in terms of complying with the objectives of the Water Framework Directive (Martinez-Santos et al. 2008b).

An immediate question arises: does it make sense for a theoretically water-scarce region to produce and export relatively low-income, water-intensive crops? The answer is not as obvious as it might appear. On the one hand farmers are interested in profitable crops, whilst water effectiveness also seems desirable in a region where a significant private investment is required to access groundwater for irrigation. Saving water is also environmentally desirable.

On the other hand, the current crop structure is the result of farmers' pursuit of cost effectiveness. Economically productive crops such as vegetables, grapes and olives are common in the region. Low economic productivity irrigated cereals are also widespread during the study period. This is probably due to the EU Common Agricultural Policy (CAP) subsidies. The 1992 CAP reform replaced price-support mechanisms with direct payments per hectare, whose amount depended on the average yields of each region. Since irrigated cereals have higher yields than the same crops under rainfed regimes, farmers with irrigated land received larger per hectare payments and had clear incentives to irrigate their crops. This scheme induced irrigation and intensified farming most acutely in arid and semi-arid regions across the EU, predominantly along the Mediterranean coastline and its hinterland (Garrido and Varela-Ortega 2008). During the studied period crops such as cereals are therefore common, as they are cost effective-partly due to subsidies-and provide a relatively safe profit. Therefore, it makes short-term economic sense for the farmers to use water as they do.

More importantly, concerning agricultural commodity trade, we have to keep in mind that the virtual water metaphor addresses water resource endowments alone. However, international trade in agricultural commodities mainly depends on factors such as availability of land, labour, technology, other resource endowments, the costs of engaging in trade, opportunity costs, national food policies and international trade agreements (Dinesh Kumar and Singh 2005; Hoekstra and Chapagain 2008). In this sense water cannot be used as the sole indicator for judging the rationality of trade patterns.

While this explains the presence of these crops in the region, water, environmental and agricultural policies have experienced substantial changes in recent times, both at the regional and the EU level. These have mostly aimed at a more rational use of water, and respond to a stronger environmental awareness on the part of 
policy-makers. In addition to the demands of the Water Framework Directive, new policies in the Mancha region essentially point at either a change in cropping patterns or a drastic reduction of the irrigated surface ( $\mathrm{CHG} 2008 \mathrm{a})$. The results of this study support this paradigm shift by showing to what extent there is an imbalance between the region's water and land uses and its natural resources. However, it is also recognized that several obstacles challenge their implementation, some of which are found at the regional and the farm scales.

These aspects suggest a first conclusion in regard to the water footprint as a tool to inform water policy. By allowing a comparison between the existing uses and the available resources the water footprint provides useful knowledge as to whether a region is using its water effectively. This tool can also be useful to inform a water rights system (Al-Weshah 2000). Actually, in the context of the Especial Plan of the Upper Guadiana (CHG 2008b), Offer of Public Purchase (OPA) has been established to address serious problems of overexploitation in the basin. In theory this basin will grant less rights than it has purchased, allocating the difference to wetlands and to increasing the piezometric levels of the aquifers (Dinar and Albiac 2009). Nevertheless, the above discussion shows how other environmental, socioeconomic and agronomic factors may pose practical challenges.

\section{Conclusions}

This paper presents an analysis of the virtual water and water footprint of agricultural production of the Mancha Occidental region, Spain, considering both hydrological and economic approaches. While relatively insufficient data renders this analysis a first approximation, it already provides an overview of the capabilities and limitations of these concepts for policy purposes.

In current times, a major challenge for agriculture is to maintain or increase the existing yields while also forfeiting water for environmental flows. Water footprint analyses can provide a transparent framework to identify potentially optimal alternatives for efficient water use at the catchment level. This can be very useful to achieve an efficient allocation of water and economic resources in the region. Nevertheless, it is recognized that this provides a partial overview of the problem, and that it may need complementary tools to balance factors such as risk diversification and labour, as well as other environmental, social, economic and agronomic considerations, particularly at the user scale.

Acknowledgements We wish to thank Alberto Garrido, Consuelo Varela, Paula Novo and Roberto Rodriguez. We would also like to thank Professor Arjen Hoekstra for his useful advices. Finally, we cannot forget the EU NeWater project and Marcelino Botin Foundation, who sponsored this research.

Open Access This article is distributed under the terms of the Creative Commons Attribution Noncommercial License which permits any noncommercial use, distribution, and reproduction in any medium, provided the original author(s) and source are credited. 


\section{References}

Al-Weshah RA (2000) Optimal use of irrigation water in the Jordan Valley: a case study. Water Resour Manag 14(5):327-338

Aldaya MM, Llamas MR (2008) Water footprint analysis for the Guadiana river basin. Value of Water Research Report Series No. 35, UNESCO-IHE Delft, The Netherlands

Allan JA (1997) 'Virtual water': a long term solution for water short Middle Eastern economies? Water Issues Group, School of Oriental and African Studies. University of London. London. Available via http://www.soas.ac.uk/faculties/lawsocialsciences.cfm?navid=2811. Accessed 15 August 2008

Allan JA (1999) Water stress and global mitigation: water food and trade. Aridlands newsl. Available via http://ag.arizona.edu/OALS/ALN/aln45/allan.html. Accessed 15 August 2008

Allan JA (2006) Virtual water, part of an invisible synergy that ameliorates water scarcity. In: Rogers P, Llamas M, Martinez-Cortina L (eds) Water crisis: myth or reality? Balkema, Rotterdam

Allen RG, Pereira LS, Raes D et al (1998) Crop evapotranspiration-guidelines for computing crop water requirements, FAO irrigation and drainage paper 56. Food and Agriculture Organization, Rome

Berbel J (2007) Análisis Económico del Uso del Agua en la Agricultura y la Ganadería. Jornadas de debate sobre El Uso del Agua en la Economía Española. Situación y Perspectivas. Grupo de Análisis Económico del Ministerio de Medio Ambiente. Sevilla, marzo de 2.007

Bromley J, Cruces J, Acreman M et al (2001) Problems of sustainable groundwater management in an area of over-exploitation: the Upper Guadiana catchment, central Spain. Water Resour Dev 17(3):379-396

Chapagain AK, Hoekstra AY (2004) Water footprints of nations. Value of Water Res Rep Ser No. 16, UNESCO-IHE, Delft, the Netherlands. Available via http://www.waterfootprint. org/?page=files/Research\%20data. Accessed 10 September 2008

Chapagain AK, Hoekstra AY, Savenije HHG et al (2006) The water footprint of cotton consumption: an assessment of the impact of worldwide consumption of cotton products on the water resources in the cotton producing countries. Ecol Econ 60(1):186-203

CHG (2008a) Información del Análisis Económico de la DHG año 2006, datos de base 2.001. Guadiana River Basin Authority, Spanish Ministry of Environment Available via http://www. chguadiana.es/. Accessed 5 July 2008

CHG (2008b) Plan Especial del Alto Guadiana. Guadiana River Basin Authority, Spanish Ministry of Environment. Available via http://www.chguadiana.es/. Accessed 5 July 2008

Comprehensive Assessment of Water Management in Agriculture (2007) Water for food, water for life: a comprehensive assessment of water management in agriculture. Earthscan, London

Dinar A, Albiac J (eds) (2009) Policy and strategic behaviour in water resource management. EarthScan

Dinesh Kumar M, Singh OP (2005) Virtual water in global food and water policy making: is there a need for rethinking? Water Resour Manag 19:759-789

Falkenmark M (2003) Freshwater as shared between society and ecosystems: from divided approaches to integrated challenges. Philos Trans R Soc B Biol Sci 358(1440):2037-2049

Falkenmark M, Rockström J (2004) Balancing water for humans and nature: the new approach in ecohydrology. Earthscan, London

FAO (2003) CROPWAT model. Food and Agriculture Organization, Rome

Fornes J, Rodríguez JA, Hernández-Mora N et al (2000) Possible solutions to avoid conflicts between water resources development and wetland conservation in the Mancha Humeda Biosphere Reserve, Spain. Phys Chem Earth 25(7):623-627

Garrido A, Varela-Ortega C (2008) Economía del agua en la agricultura e integración de políticas sectoriales. Panel de Estudios. Universidad de Sevilla-Ministerio de Medio Ambiente, pp 1-33

Hernández-Mora N, Llamas MR, Martínez-Cortina L (2001) Misconceptions in aquifer overexploitation. Implications for water policy in Southern Europe. In: Dosi C (ed) Agricultural use of groundwater: towards integration between agricultural policy and water resources management. Kluwer, Dordrecht, pp 107-125

Hernández-Mora N, Martinez-Cortina L, Llamas MR et al (2007) Groundwater issues in Southern EU Member States. Spain Country Report. Available via http://rac.es/2/2_ficha.asp? id=119\&idN3=6\&idN4=40. Accessed 15 March 2008 
Hoekstra AY (ed) (2003) Virtual water trade: Proceedings of the international expert meeting on virtual water trade, Delft, The Netherlands, 12-13 December 2002. Value of Water Research Report Series No.12, UNESCO-IHE, Delft, the Netherlands

Hoekstra AY, Chapagain AK (2007) Water footprints of nations: water use by people as a function of their consumption pattern. Water Resour Manag 21:35-48

Hoekstra AY, Chapagain AK (2008) Globalization of water: sharing the planet's freshwater resources. Blackwell, Oxford

Hoekstra AY, Hung PQ (2005) Globalisation of water resources: international virtual water flows in relation to crop trade. Glob Environ Chang 15(1):45-56

ICEX (2008) Spanish Institute for Foreign Trade. Available via http://www.icex.es/icex/cda/ controller/pageICEX/0,6558,5518394_5518974_5536731_0_0_-1,00.html. Accessed 10 June 2008

INE (2007) National Statistics Institute. Available via http://www.ine.es/. Accessed 5 September 2008

INM (2007) National Institute of Meteorology, Spanish Ministry of Environment. Available via http://www.inm.es/. Accessed 8 September 2008

Llamas MR (1988) Conflicts between wetland conservation and groundwater exploitation: two case histories in Spain. Environ Geol Water Sci 11(3):241-251

Llamas MR, Martínez-Santos P (2005) Intensive groundwater use: silent revolution and potential source of social conflicts. J Water Resour Plan Manag, American Society of Civil Engineers, September-October 2005, pp 337-341

MAPA (1999) 1T sheets. Spanish Ministry of Agriculture, Fisheries and Food

MAPA (2001) Calendario de siembra, recolección y comercialización, años 1996-1998. Spanish Ministry of Agriculture, Madrid, $656 \mathrm{p}$

MAPA (2006) Agro-alimentary statistics yearbook. Spanish Ministry of Agriculture, Fisheries and Food Available via http://www.mapa.es/es/estadistica/pags/anuario/Anu_06/indice.asp?parte=2 \&capitulo=16. Accessed 5 September 2008

MAPA (2007) Agro-alimentary statistics yearbook. Spanish Ministry of Agriculture, Fisheries and Food. Available via http://www.mapa.es/es/estadistica/pags/anuario/introduccion.htm. Accessed 5 September 2008

Martinez-Santos P, De Stefano L, Martínez-Alfaro PE et al (2008a) Wetland restoration in the Mancha Occidental aquifer, Spain: a critical perspective on water, agricultural and environmental policies. Restor Ecol 16(3):511-521

Martinez-Santos P, Llamas MR, Martinez-Alfaro PE (2008b) Vulnerability assessment of groundwater resources: a modelling-based approach to the Mancha Occidental aquifer, Spain. Environ Modelling Softw 23(9):1145-1162

MIMAM (2007) El agua en la economía española: Situación y perspectivas. Spanish Ministry for the Environment Available via http://circa.europa.eu/Public/irc/env/wfd/library?l=/framework_ directive/implementation_documents_1/wfd_reports/member_states/spain/article_5/completo_ nivel1pdf/_EN_1.0_\&a=d. Accessed 20 May 2008

Rockström J (2001) Green water security for the food makers of tomorrow: windows of opportunity in drought-prone savannahs. Water Sci Technol 43(4):71-78

Vives R (2003) Economic and social profitability of water use for irrigation in Andalusia. Water Int 28(3):326-334

WWF (2008) Living planet report 2008. Gland: world wide fund for nature. Available via www. panda.org. Accessed 15 June 2009 